\title{
Survival in surgical non-small cell lung cancer in a French Hospital
}

\section{Survie d'un cancer bronchique non à petites cellules dans un hôpital français}

\author{
C. Clément-Duchêne Christelle1,2, I. Lemonnier, F. Guillemin Francis ${ }^{3}$, JP. Vignaud ${ }^{4}$, G. Gauchotte, \\ S. Lacomme ${ }^{4}$, J. Siat ${ }^{5}$, Y. Martinet ${ }^{6}$
}

1: Institut de Cancérologie de Lorraine, Oncology Department, Nancy, France

2: Centre de Recherche en Automatique de Nancy (CRAN), Nancy, France

3: University Hospital, Clinical Epidemiology and Evaluation Department, Nancy, France

4: University Hospital, Pathology Department, Nancy, France

5: University Hospital, Surgery Department, Nancy, France

6: University Hospital, Chest Department, Nancy, France

\begin{abstract}
Background. Lung cancer staging with positron emission tomography, and adjuvant treatments (AT) have been progressively used for the management of surgical non-small cell lung cancer (NSCLC). Aim and methods. The objective of this retrospective study was to analyze the survival of surgically NSCLC in a French University hospital. This study included 1 562 patients between 1988 and 2011. Patients were assigned into 2 groups: G1=before PET, and AT introduction (19882002); G2=after PET, and AT introduction (2003-2011). Patients' clinical profile and survival were described, and compared using the Kaplan-Meïer method and Log-rank test. A multivariate analysis was conducted with a Cox model. Results. Adenocarcinoma was the most frequent histological types in G2 (38.8\%, p<0.0001). The percentage of women (G2: $21.2 \%$ vs G1: $13.1 \%, p<0.0001)$ as well as of non-smokers increased over time $(7.3 \%$ vs $6.9 \%, p=0.009)$, and also for early stages NSCLC $(29.2 \%$ vs $15.5 \%$, p < 0.0001$)$. Comparing G2 to G1, more patients underwent an association of chemotherapy and radiotherapy after surgery $(4.9 \%$ vs $1.2 \%)$, and postoperative chemotherapy was also more frequent $(20.8 \%$ vs $6.5 \%$, $\mathrm{p}<0.0001)$. G2 patients vs G1 had a better one-year survival $(70 \%$ vs $48 \%, \mathrm{p}<0.0001)$. Women had a better survival for the whole cohort $(\mathrm{HR}<0.0001)$, in $\mathrm{G} 1(\mathrm{HR}<0.0001)$, and $\mathrm{G} 2(\mathrm{HR}=0.03)$. The Cox model found a lower risk in $\mathrm{G} 2$ period $(\mathrm{HR}=0.52$ [0.40-0.66] for adenocarcinoma, and $\mathrm{HR}=0.64$ [0.50-0.80] for squamous carcinoma. Conclusions. The survival of surgically NSCLC raised since 2003, with probably an impact of epidemiological, diagnostic, and therapeutic changes.
\end{abstract}

KEYWORDS: Non-small cell lung cancer; PET; Thoracic surgery; Survival.

\section{RÉSUMÉ}

Introduction. La stadification du cancer du poumon avec tomographie par émission de positrons et les traitements adjuvants (TA) ont été progressivement utilisés pour la gestion du cancer du poumon non à petites cellules (CBNPC) chirurgical. But et méthodes. L'objectif de cette étude rétrospective était d'analyser la survie du CBNPC chirurgical dans un hôpital universitaire français. Cette étude comprenait 1562 patients entre 1988 et 2011. Les patients ont été répartis en 2 groupes: G1 = avant TEP et introduction d'AT (1988-2002); G2 = après la TEP et l'introduction d'AT (2003-2011). Le profil clinique et la survie des patients ont été décrits et comparés à l'aide de la méthode de Kaplan-Meïer et du test Log-rank. Une analyse multivariée a été réalisée avec un modèle de Cox. Résultats. L'adénocarcinome était les types histologiques les plus fréquents chez G2 (38,8\%, p <0,0001). Le pourcentage de femmes (G2: 21,2\% contre G1: 13,1\%, p <0,0001) ainsi que de nonfumeurs a augmenté avec le temps $(7,3 \%$ contre $6,9 \%, p=0,009)$, ainsi que pour les stades précoces de cancer du poumon non à petites cellules $(29,2 \%)$. vs $15,5 \%, \mathrm{p}<0,0001)$. En comparant G2 à G1, davantage de patients ont subi une association de chimiothérapie et de radiothérapie après une chirurgie $(4,9 \%$ contre 1,2\%) et la chimiothérapie postopératoire était également plus fréquente $(20,8 \%$ contre $6,5 \%, \mathrm{p}<0,0001)$. Les patients $\mathrm{G} 2$ vs G1 avaient une meilleure survie à un an $(70 \%$ vs $48 \%, \mathrm{p}<0,0001)$. Les femmes avaient une meilleure survie pour l'ensemble de la cohorte $(\mathrm{HR}<0,0001)$, en G1 (HR <0,0001) et en $\mathrm{G} 2(\mathrm{HR}=0,03)$. Le modèle de Cox a révélé un risque plus faible pendant la période $\mathrm{G} 2(\mathrm{HR}=0,52[0,40-0,66]$ pour l'adénocarcinome et $\mathrm{HR}=0,64$ [0,50-0,80] pour le carcinome épidermoïde. Conclusions. La survie du CBNPC chirurgical élevé depuis 2003, avec probablement un impact des changements épidémiologiques, diagnostiques et thérapeutiques.

MOTS CLÉS: Cancer du poumon non à petites cellules; PET; Chirurgie thoracique; Survie.

Corresponding author: Dr. CHRISTELlE CLÉMENT-DuCHÊNE. Département d'Oncologie Médicale, Institut de Cancérologie de Lorraine, 54500 Vandoeuvre-lès-Nancy, France. E-mail: christelle.clementduchene@gmail.com 


\section{INTRODUCTION}

Lung cancer is the leading cause of death by cancer in the world. Its incidence is still rising, and its prognosis remains poor, with a 5-years survival of about $15 \%$ [1]. Only $20 \%$ of lung cancers can benefit from surgical treatment. For the other patients, chemotherapy and radiation remain only treatments [2].

In order to select patients suitable for surgery, a complete CT-Scan staging with a respiratory, and cardiovascular assessment are required. Over the last decade, staging with positron emission tomography (PET) has progressively shown to be more sensitive, and efficient than conventional CT-Scan in selecting patients for surgery; thus, PET is now routinely used [3,4].

Importantly, in the mean time, while PET was progressively introduced, lung cancer treatments also evolved due to several trials showing adjuvant treatment (AT) efficacy for patients undergoing surgery for lung cancer, namely chemotherapy, and/or thoracic radiotherapy [5]. Secondly, since 2005, adjuvant treatment prescriptions have been more frequent [6].

The aim of this paper is to evaluate the survival of surgically non-small cell lung cancer (NSCLC) in a cohort of 1562 consecutive subjects undergoing surgery from 1988 to 2011 at Nancy University Hospital. The other aim was to identify the prognostic factors.

\section{MATERIAL AND METHODS}

\section{Patients and study design}

The CRB biobank (Centre de Ressources Biologiques) was created in 1988, and data from all consecutive surgically treated lung cancers were collected. For each patient, clinical, histological, and therapeutic data were extracted from this biobank patients' records, including: gender, age, histological type according to WHO classification [7,8], smoking status defined as follows: patients who had quit smoking for more than one year were considered former smokers, and patients who had smoked less than 100 cigarettes in their lifetime were defined as never smokers, TNM stage according to the WHO 2009 classification [9], type of surgery, use of neoadjuvant or adjuvant chemotherapy, and/or radiation, and comorbidities (other cancers, other respiratory diseases, other diseases). All patients underwent a CT and brain scan, and all patients in G2 underwent a PET. Every 6 months, a systematic followup of all surviving patients was carried out, by asking their physicians. Patients received AT according to ASCO, and ESMO guidelines, according to TNM staging, comorbidities, and performance status [10]. All patients were discussed in tumor board, and stage Ib>4 cm, II, III have been treated by chemotherapy (cisplatine-vinorelbine or carboplatinepaclitaxel) and/or thoracic radiation for $\mathrm{pN} 2$.

In order to analyze the survival of surgically NSCLC, we created two groups of patients, those undergoing surgery from 1988 to Dec 31 $1^{\text {st }} 2002$, before PET local availability for staging, and AT (First group=G1), and those followed since Jan $1^{\text {st }} 2003$ up to Dec 31 $1^{\text {st }}$ 2011, after PET availability, and AT (Second group=G2).

\section{Statistical analysis}

Patients' socio-demographic and clinical characteristics were described with mean \pm standard deviation (SD) for quantitative and percentage for qualitative variables. To test the association between variables, the chi-square or Fisher exact test was used for qualitative and Student $t$ test or Mann-Whitney test for quantitative variables. Using survival as the outcome, we determined the time to event (death) from the day of surgery to the day of death (due to any cause $=$ overall survival). In order to observe at least 1 year of follow up for all patients, we decided to keep only patients who underwent surgery up to Dec 31, 2011.

Patients who were alive after Dec 31, 2011 or were lost to follow-up were censored. Survival curves were estimated by the Kaplan-Meier method and compared by the log rank test. Bivariate then multivariate analyses involved use of the Cox proportional hazards model to identify factors related to survival: period, age (as a continuous variable), sex, smoking status, cancer stage, and treatments. An analyze according to histological type was done. The proportionality assumption was checked for each of the variables under study with scaled Schoenfeld residuals and by the proportionality test [11-13]. Data were analyzed by use of SAS, v9.3 (SAS Inst. Inc, Cary, NC). Type I error threshold was set at 0.05 .

\section{RESULTS}

\section{Patients}

Socio-demographic characteristics

A total of 1562 patients undergoing surgery for lung cancer were included in this study, 765 patients for the first period from 1988 to December 2002 (G1), and 797 patients for the second period from January 2003 to 2011 (G2).

The proportion of women diagnosed with lung cancer was higher in the after- compared to beforeperiod $(21.2 \%$ vs $13.1 \%, \mathrm{p}<0.001)$. Interestingly, there were less smokers in the after- compared to beforeperiod $(86.3 \%$ vs $90.7 \%$, $\mathrm{p}<0.001)$. No mean age difference was observed (Table 1). 


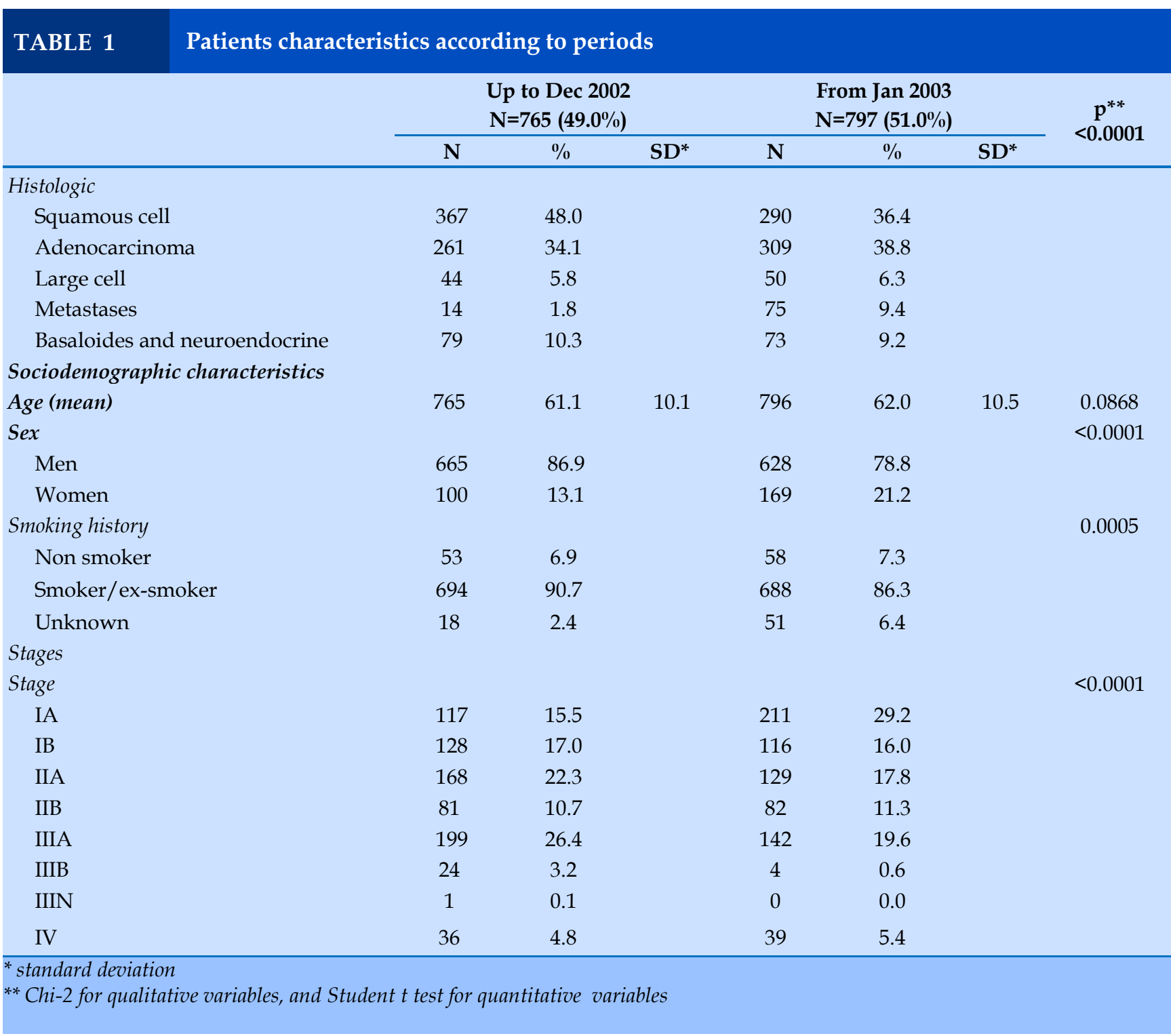

\section{Clinical characteristics}

Squamous cell carcinoma was the most frequent histological type up to 2002 vs adenocarcinoma (48.0\% vs $34.1 \%$ ), and then, on the opposite, adenocarcinoma outnumbered squamous cell carcinoma after 2003 (38.8\% vs 36.4\%, $\mathrm{p}<0.0001)$. More patients were diagnosed with stage IA since 2003 (29.2\% vs $15.5 \%$, $\mathrm{p}<0.0001$ ). Interestingly, a familial, and personal history of cancer was more frequent after 2003 (familial: $26.0 \%$ vs $6.1 \%, \mathrm{p}<0.0001$, and personal: $18.0 \%$ vs $11.9 \%, \mathrm{p}=0.005)$.

In the whole cohort, patients with adenocarcinoma, large cell carcinoma as well as basaloidesneuroendocrine, were younger than those with squamous cell carcinoma $(60.4,59.9,57.8$ vs 63.5 years, $\mathrm{p}<0.0001$ respectively). Adenocarcinoma, and large cell carcinoma were the most frequent histological types in women (adenocarcinoma: $45.4 \%$, large cell: $19.3 \%, \mathrm{p}<0.001)$. Adenocarcinoma were more frequent in non-smokers compared to other histological types $(10.9 \%$ vs $1.7 \%$ for squamous cell carcinoma, and $33.6 \%$ for large cell carcinoma, $\mathrm{p}<0.0001$ ).
Patients with early stages were more frequent in non -smokers compared to more advanced stage $(27.9 \%$ in stage IA, vs $7.0 \%$ in stage IV, $\mathrm{p}<0.0001)$. Concerning squamous cell carcinoma, pneumonectomies were more frequent than in adenocarcinoma $(35.0 \%$ vs $18.6 \%, \mathrm{p}<0.0001)$. Lobectomies were more frequent in adenocarcinoma than squamous cell carcinoma $(76.0 \%$ vs $58.0 \%$, p<0.0001), while adjuvant chemotherapy was more frequent in adenocarcinoma than squamous cell carcinoma $(14.4 \%$ vs $9.0 \%$, $\mathrm{p}<0.0001)$ - Data not shown.

In patients with squamous cell carcinoma, when comparing the second period to the first one, on an average patients were older (64.5 \pm 9.4 vs $62.7 \pm 9.5$; $\mathrm{p}=0.01)$ and there were less smokers ( $94.1 \%$ vs $97.3 \%$; $\mathrm{p}=0.04)$.

As for adenocarcinoma, when comparing the second period to the first one, the percentage of women increased $(24.6 \%$ vs $17.6 \%, \mathrm{p}<0.04)$, while the percentage of non-smokers remained stable $(10.7 \%$ vs $11.1 \%$, 
$\mathrm{p}<0.3)$. No difference in their mean age was observed.

\section{Anticancer treatments associated to surgery}

Nearly $95 \%$ of the whole patients have been discussed in a tumor board. Comparing the second period to the first one, more patients underwent an association of chemotherapy and radiotherapy after surgery (4.9\% vs $1.2 \%)$, and postoperative chemotherapy was also more frequent $(20.8 \%$ vs $6.5 \%$, $\mathrm{p}<0.0001)$.

\section{Patients' survival}

Overall, patients undergoing surgery during the second period had a better 1 year survival probability than patients followed during the first period $70 \%$ vs $48 \%$, (Figure 1, Table 2), and this was the case for adenocarcinoma $69 \%$ vs $48 \%$, as well as for squamous cell carcinomas $68 \%$ vs $47 \%$, and for N1 disease $43 \%$ vs $53 \%$, and N2 disease $28 \%$ vs $48 \%$ (Table 2).

\begin{tabular}{|c|c|c|c|c|c|}
\hline \multirow[t]{3}{*}{ TABLE 2} & \multicolumn{5}{|c|}{$\begin{array}{l}1 \text { year and } 2 \text { years survival according } \\
\text { to periods }\end{array}$} \\
\hline & \multicolumn{2}{|c|}{$\begin{array}{l}\text { Survival } \\
\text { before } 2003\end{array}$} & \multicolumn{2}{|c|}{$\begin{array}{l}\text { Survival after } \\
2003\end{array}$} & \multirow[b]{2}{*}{$\mathrm{p}$} \\
\hline & $\begin{array}{c}1 \\
\text { year }\end{array}$ & $\begin{array}{c}2 \\
\text { years }\end{array}$ & $\begin{array}{c}1 \\
\text { year }\end{array}$ & $\begin{array}{c}2 \\
\text { years }\end{array}$ & \\
\hline Cohort & 0.49 & 0.40 & 0.70 & 0.63 & $<0.001$ \\
\hline N1 & 0.43 & 0.32 & 0.53 & 0.43 & 0.009 \\
\hline N2 & 0.28 & 0.19 & 0.48 & 0.37 & $<0.001$ \\
\hline $\begin{array}{l}\text { Adenocarci- } \\
\text { noma }\end{array}$ & 0.48 & 0.37 & 0.66 & 0.61 & $<0.001$ \\
\hline $\begin{array}{l}\text { Squamous } \\
\text { cells }\end{array}$ & 0.48 & 0.42 & 0.68 & 0.60 & $<0.001$ \\
\hline
\end{tabular}

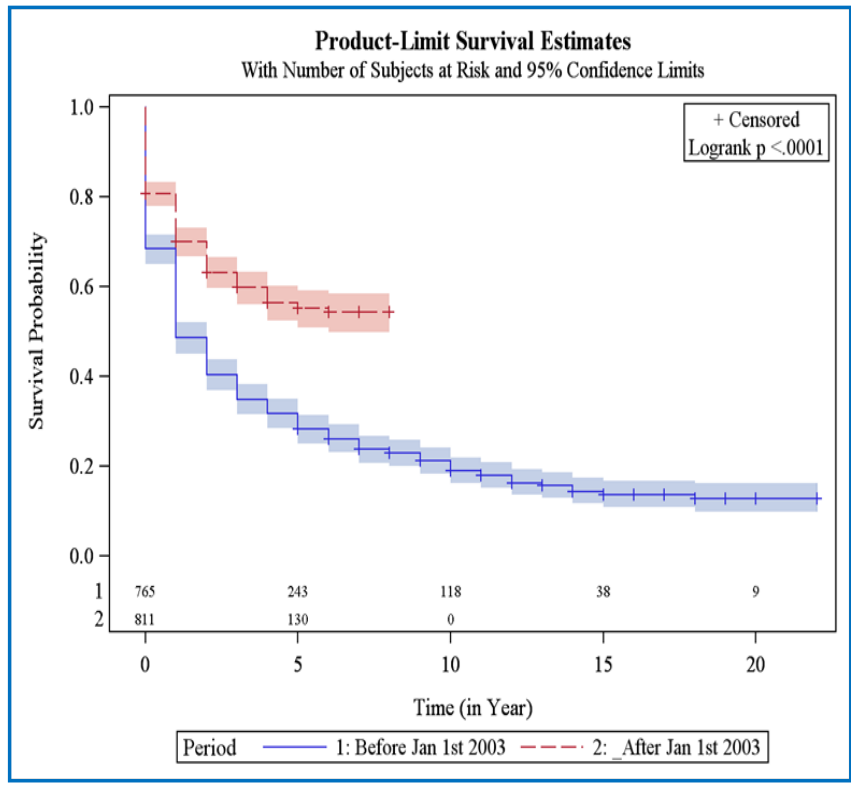

FIGURE 1. Survival of the cohort according to periods.
Interestingly, women's probability to survive at 1 year after surgery was better than men $(67 \%$ vs $58 \%$, $\mathrm{p}<0.001)$ for the entire cohort. For the first period, they had a better 1 year survival probability than men $(59 \%$ vs $47 \%, p=0.0006)$, and as well for the second period ( $73 \%$ vs $68 \%, p=0.03)$. Finally, for all patients diagnosed with an adenocarcinoma, women had a better 1 year survival probability than men (67\% vs $57 \%$, $\mathrm{p}=0.02)$; while for squamous cell carcinomas, no difference was observed (58\% vs 57\% $\mathrm{p}=0.2)$.

In the whole cohort, non-smokers had a better 1 year survival than current smokers and ex-smokers combined $(70 \%$ vs $59 \%, \mathrm{p}=0.004)$. The 1 year survival difference was also observed when comparing the smoking status according to period. Sixty-three percent of non-smokers in the period before-PET availability were more likely to be alive 1 year after the operation compared to $47 \%$ only if they were smokers $(p=0.01)$, but no difference was observed for nonsmokers vs smokers in the period after $(75 \%$ vs $70 \%$, $\mathrm{p}=0.3)$.

For patients diagnosed with an adenocarcinoma, $70 \%$ of non-smokers were more likely to be alive after 1 year compared to $59 \%$ in smokers, $p=0.04$. In contrast, in patients with squamous cell, no statistically significant difference in 1 year survival between non-smokers vs smokers was observed (58\% vs $37 \%$, $\mathrm{p}=0.07)$.

Factors related to patients' survival

Adenocarcinoma $(\mathrm{n}=570)$

In bivariate analysis, period, sex, smoking status, disease stage and treatments independently predicted patients' survival. In multivariate analysis, patients in the G2 group had a lower risk of death (Hazard Ratio $(\mathrm{HR})=0.52$ [CI 95\% $0.40-0.66$ ], $\mathrm{p}<0.001)$ compared to those in the 1 group. Older age $(\mathrm{HR}=1.02$ [1.01 - 1.03], $\mathrm{p}<0.002)$, unknown status of smoking history $(\mathrm{HR}=2.37$ [1.14 - 4.91], $\mathrm{p}=0.02$, higher stages of cancer $(\mathrm{HR}=1.58-19.95$, $\mathrm{p}<0.001)$, and treatments with surgical act $(\mathrm{HR}=2.13$ - $3.30, p=0.002$ to $p<0.001$ ) were related to a higher risk of death.

No interaction between variables was observed (Table 3).

Squamous cell carcinoma $(n=657)$

In the bivariate analysis, period, stages of cancer and treatments independently predicted survival. In multivariate analysis, patients in the after-PET period had lower risk of death $(\mathrm{HR}=0.64$ [0.50 - 0.80], $\mathrm{p}<0.001)$. Stages IIB to IV of cancer were related to a higher risk of death $(\mathrm{HR}=1.65-3.62, \mathrm{p}=0.01$ to $\mathrm{p}<0.001)$. No interaction between variables was observed (Table 4). 
TABLE 3 Factors related to the survival of patients with adenocarcinoma

\begin{tabular}{|c|c|c|c|c|c|c|}
\hline \multirow{3}{*}{ Variables } & \multicolumn{6}{|c|}{ Adenocarcinoma $(n=570)$} \\
\hline & \multicolumn{3}{|c|}{ Bivariate analysis } & \multicolumn{3}{|c|}{ Multivariate analysis } \\
\hline & HR & $95 \% \mathrm{CI}$ & $\mathbf{p}$ & HR & $95 \% \mathrm{CI}$ & $\mathbf{p}$ \\
\hline \multicolumn{7}{|l|}{ Period } \\
\hline - Before-PET & 1 & & & 1 & & \\
\hline - After-PET & 0.494 & $0.395-0.619$ & $<0.001$ & 0.517 & $0.402-0.665$ & $<0.001$ \\
\hline \multicolumn{7}{|l|}{ Sociodemographic characteristics } \\
\hline Age & 0.994 & $0.975-1.014$ & 0.56 & 1.019 & $1.007-1.031$ & 0.002 \\
\hline \multicolumn{7}{|l|}{ Sex } \\
\hline - Men & 1 & & & 1 & & \\
\hline - Women & 0.750 & $0.570-0.987$ & 0.04 & 0.894 & $0.642-1.243$ & 0.50 \\
\hline \multicolumn{7}{|l|}{ Smoking status } \\
\hline - Non smoker & 1 & & & 1 & & \\
\hline - Smokers / ex-smokers & 1.391 & $0.966-2.002$ & 0.08 & 1.505 & $0.968-2.340$ & 0.07 \\
\hline - Unknown & 2.045 & $1.050-3.982$ & 0.04 & 2.366 & $1.140-4.910$ & 0.02 \\
\hline \multicolumn{7}{|l|}{ Clinical characteristic } \\
\hline \multicolumn{7}{|l|}{ Stage of cancer } \\
\hline IA & 1 & & & 1 & & \\
\hline IB & 1.399 & $0.977-2.001$ & 0.07 & 1.580 & $1.058-2.360$ & 0.03 \\
\hline IIA & 1.766 & $1.250-2.497$ & 0.001 & 2.333 & $1.465-3.718$ & $<0.001$ \\
\hline IIB & 2.253 & $1.419-3.579$ & $<0.001$ & 5.003 & $2.512-9.965$ & $<0.001$ \\
\hline IIIA & 2.930 & $2.136-4.020$ & $<0.001$ & 8.856 & $3.933-19.927$ & $<0.001$ \\
\hline IIIB & 6.579 & $3.512-12.326$ & $<0.001$ & 22.890 & $7.324-71.536$ & $<0.001$ \\
\hline IV & 2.753 & $1.773-4.272$ & $<0.001$ & 19.956 & $6.007-66.293$ & $<0.001$ \\
\hline \multicolumn{7}{|l|}{ Treatments } \\
\hline - Surgery only & 1 & & & 1 & & \\
\hline - Chemotherapy only & 2.794 & $0.391-19.967$ & 0.31 & 4.170 & $0.523-33.262$ & 0.18 \\
\hline - Surgery and Chemotherapy & 1.422 & $1.057-1.912$ & 0.02 & 2.134 & $1.387-3.282$ & $<0.001$ \\
\hline - Surgery and Radiotherapy & 1.966 & $1.502-2.572$ & $<0.001$ & 2.573 & $1.457-4.512$ & 0.001 \\
\hline - Surgery and Chemo-Radiotherapy & 1.489 & $1.055-2.102$ & 0.02 & 3.304 & $1.531-7.131$ & 0.002 \\
\hline \multicolumn{7}{|l|}{ Interactions } \\
\hline Age by sex & 0.997 & $0.972-1.024$ & 0.86 & & & \\
\hline Age by smoking status & 1.005 & $0.975-1.036$ & 0.74 & & & \\
\hline Age by treatments & 1.000 & $0.993-1.007$ & 0.99 & & & \\
\hline Sex by smoking status & 1.235 & $0.621-2.458$ & 0.55 & & & \\
\hline Sex by treatments & 0.967 & $0.812-0.151$ & 0.70 & & & \\
\hline Smoking status by treatments & 1.137 & $0.925-1.397$ & 0.22 & & & \\
\hline Age by stage of cancer & 0.998 & $0.993-1.004$ & 0.61 & & & \\
\hline Sex by stage of cancer & 1.059 & $0.913-1.228$ & 0.45 & & & \\
\hline Period by treatments & 1.121 & $0.959-1.311$ & 0.15 & & & \\
\hline
\end{tabular}


TABLE 4 Factors related to the survival of patients with squamous cell

\begin{tabular}{|c|c|c|c|c|c|c|}
\hline \multirow{3}{*}{ Variables } & \multicolumn{6}{|c|}{ Squamous cell $(n=657)$} \\
\hline & \multicolumn{3}{|c|}{ Bivariate analysis } & \multicolumn{3}{|c|}{ Multivariate analysis } \\
\hline & HR & $95 \% \mathrm{CI}$ & $\mathrm{p}$ & HR & $95 \% \mathrm{CI}$ & $\mathrm{p}$ \\
\hline \multicolumn{7}{|l|}{ Period } \\
\hline Before-PET & 1 & & & 1 & & \\
\hline After-PET & 0.621 & $0.503-0.767$ & $<0.001$ & 0.636 & $0.503-0.805$ & $<0.001$ \\
\hline \multicolumn{7}{|l|}{ Sociodemographic characteristics } \\
\hline Age & 1.012 & $0.994-1.030$ & 0.19 & 0.982 & $0.936-1.031$ & 0.47 \\
\hline \multicolumn{7}{|l|}{ Sex } \\
\hline - Men & 1 & & & 1 & & \\
\hline - Women & 0.818 & $0.571-1.173$ & 0.27 & 0.093 & $0.005-1.643$ & 0.11 \\
\hline \multicolumn{7}{|l|}{ Smoking status } \\
\hline - Non smoker & 1 & & & 1 & & \\
\hline - Smokers / ex-smokers & 0.810 & $0.402-1.633$ & 0.56 & 1.019 & $0.486-2.138$ & 0.96 \\
\hline - Unknown & 1.488 & $0.586-3.782$ & 0.40 & 2.361 & $0.886-6.290$ & 0.09 \\
\hline \multicolumn{7}{|l|}{ Clinical characteristic } \\
\hline \multicolumn{7}{|l|}{ Stage of cancer } \\
\hline IA & 1 & & & 1 & & \\
\hline IB & 0.975 & $0.682-1.394$ & 0.89 & 0.925 & $0.645-1.326$ & 0.67 \\
\hline IIA & 1.378 & $1.002-1.897$ & 0.05 & 1.272 & $0.917-1.763$ & 0.15 \\
\hline IIB & 1.853 & $1.303-2.635$ & $<0.001$ & 1.647 & $1.148-2.362$ & 0.007 \\
\hline IIIA & 2.364 & $1.731-3.228$ & $<0.001$ & 2.166 & $1.546-3.034$ & $<0.001$ \\
\hline IIIB & 4.628 & $2.414-8.872$ & $<0.001$ & 3.622 & $1.849-7.095$ & $<0.001$ \\
\hline IV & 2.353 & $1.263-4.384$ & 0.007 & 2.256 & $1.186-4.289$ & 0.01 \\
\hline \multicolumn{7}{|l|}{ Treatments } \\
\hline - Surgery only & 1 & & & 1 & & \\
\hline - Surgery and Chemotherapy & 1.065 & $0.786-1.442$ & 0.69 & 1.175 & $0.842-1.639$ & 0.34 \\
\hline - Surgery and Radiotherapy & 1.538 & $1.212-1.951$ & $<0.001$ & 1.123 & $0.853-1.477$ & 0.41 \\
\hline - Surgery and Chemo-Radiotherapy & 1.107 & $0.813-1.506$ & 0.52 & 1.014 & $0.724-1.420$ & 0.94 \\
\hline \multicolumn{7}{|l|}{ Interactions } \\
\hline Age by sex & 1.047 & $1.003-1.093$ & 0.04 & 1.038 & $0.992-1.085$ & 0.11 \\
\hline Age by smoking status & 1.027 & $0.956-1.103$ & 0.47 & & & \\
\hline Age by treatments & 1.003 & $0.997-1.010$ & 0.33 & & & \\
\hline Sex by smoking status & 1.138 & $0.270-4.802$ & 0.86 & & & \\
\hline Sex by treatments & 1.019 & $0.816-1.272$ & 0.87 & & & \\
\hline Age by stage of cancer & 0.998 & $0.991-1.004$ & 0.47 & & & \\
\hline Sex by stage of cancer & 1.127 & $0.897-1.415$ & 0.31 & & & \\
\hline Period by treatments & 0.986 & $0.854-1.138$ & 0.85 & & & \\
\hline
\end{tabular}

Note: The multivariate analysis included also the interaction between age and sex. 


\section{DISCUSSION}

This study, including 1562 patients undergoing thoracic surgery, shows that over last 25 years, adenocarcinoma became the most frequent lung cancer histological type, that the proportion of women and non-smokers diagnosed with lung cancer increased, and that more early stages (stage I) were treated by surgery [14-19]. We observed that, as a whole, patients undergoing surgery for lung cancer diagnosed since 2003, when PET, and AT began to be adopted in daily practice, had a better 1 year and 2 years survival than those diagnosed before. In the same way, women and non-smokers experienced a better survival over the same period. Finally, patients undergoing surgery for adenocarcinoma or squamous cell carcinoma with $\mathrm{N} 1$ or N2 staging, had a lower risk of death at 1 and 2 years in the second period compared to those treated in the first one.

Our paper has some limitations. Firstly, it is a monocenter study, and readers should be cautious in generalizing the results. Secondly, comorbidities were not taken into account in the survival analysis. Notwithstanding, the number of patients included in this study, and the duration of the follow-up allow to draw significant conclusions.

Evolution of clinical profile of patients undergoing surgery for lung cancer over a period from 1988 to 2011

All our observations in this respect are consistent with the international literature. Indeed, adenocarcinoma was the most frequent histological type in our study, and its frequency increased from 1988 to 2011, from $34.1 \%$ to $38.8 \%$, as previously observed in several reviews of the literature [20-23].

The percentage of women significatively increased from $13.1 \%$ to $21.2 \%$ in our observation. This is in accord with several previous, and recent publications [14-19].

In respect to smoking status, we observed a slight significant increase of non-smokers percentage from $6.9 \%$ to $7.6 \%$, and this has already been shown in the literature [24 25].

Finally, the percentage of early stages among these patients undergoing surgery increased from $15.5 \%$ to $29.2 \%$, as already published [20].

\section{Evolution of patients' survival over a period from} 1988 to 2011

Survival curves evaluation according to the KaplanMeiër method demonstrated a far better survival of patients undergoing surgery after PET, and AT introduction, with a 1 year survival of $49 \%$ in the first period, and $70 \%$ in the second one, and a 2 years survival of $40 \%$ in the first period, and $63 \%$ in the second one.
Taking into account the main observations found on the clinical profile of patients undergoing surgery for lung cancer, this significant increased survival could be explained by 5 main raisons, possibly combined: increase incidence of adenocarcinoma: in the literature, this histological type has been shown to be associated with a better survival than squamous cell carcinoma [20]. However, in our study, the separate analysis of adenocarcinoma showed a better survival for those diagnosed, and followed after 2003; thus, it is not likely that this increased percentage of adenocarcinoma played a major role in the improvement of survival.

Increase of the percentage of women: in the literature, women, with the same clinical profile (age, histological type, TNM staging), do have a better survival than men 26-34. This was the case in our study, since women had a better overall survival from 1988 to 2011; however we also found that women survival was better for those treated after 2003; thus, it is not likely that this increased percentage of women played a major role in the improvement of survival. Increase of the percentage of non-smokers: in the literature, non-smokers have a better survival than smokers [35-38]. However, the increase of the percentage of non-smokers observed in our study was too small to explain the observed better survival.

Increase of the percentage of early stages: since the introduction of PET scan, the percentage of patients undergoing surgery for early stages has increased, suggesting that some patients diagnosed as late stages before PET avaibility were in fact more advanced cases which should not have been operated [3]. With the introduction of PET scan, the quality of mediastinal staging, and of the extrathoracic extension evaluation have improved, leading to a pre-surgery TNM staging of better accuracy. Thus the better survival could result from the absolute increase of lung cancer with early stages, but more importantly from a better selection of patients before surgery [39]. Few studies have analyzed the impact of PET on lung cancer survival. Dinan et al. included 97007 patients with NSCLC, in a retrospective analysis of Surveillance, Epidemiology, and End Results (SEER) between 1998 and 2003, and found that PET introduction did not change the overall survival. The authors explained this finding by the fact that PET, at that time, was preferentially used in early lung cancer staging [40]. In a review of the literature on PET/CT use in therapy evaluation of patients with lung cancer, Langer et al. have shown that PET has a prognostic value [4].

Increase of the percentage of patients undergoing AT: some studies have demonstrated an increase of survival with AT in NSCLC [6,41-44]. Indeed, in the ANITA trial (Adjuvant Navelbine International Trialist Association), 840 stage IB-IIIA NSCLC were 
included to receive cisplatin-vinorelbine or observation after surgery. After a median follow-up of 76 months, median survival was 65.7 months in the chemotherapy group, and 43.7 months in the observation group. The 5 years survival increased by $8.6 \%$ in the chemotherapy group ${ }^{41}$. Furthermore, in the CALGB 9633 trial, 344 stage IB NSCLC were randomized between chemotherapy (carboplatinpaclitaxel) or observation after surgery. Patients with tumors size $\geq 4$ centimeters had a significant better survival in the chemotherapy group [43].

\section{CONFLIT OF INTERESTS}

Non.

\section{REFERENCES}

1. Jemal A, Siegel R, Ward E, et al. Cancer statistics. CA Cancer J Clin 2009;59(4):225-49.

2. Bunn PA, Jr., Thatcher N. Systemic treatment for advanced (stage IIIb/IV) non-small cell lung cancer: more treatment options; more things to consider. Conclusion. Oncologist 2008;13 Suppl 1:37-46.

3. Schrevens L, Lorent N, Dooms C, et al. The role of PET scan in diagnosis, staging, and management of nonsmall cell lung cancer. Oncologist 2004;9(6):633-43.

4. Langer NH, Christensen TN, Langer SW, et al. PET/ CT in therapy evaluation of patients with lung cancer. Expert Rev Anticancer Ther 2014;14(5):595-620.

5. Artal Cortes A, Calera Urquizu L, Hernando Cubero J. Adjuvant chemotherapy in non-small cell lung cancer: state-of-the-art. Transl Lung Cancer Res 2015;4(2):191-7.

6. Besse B, Le Chevalier T. Adjuvant chemotherapy for non-small-cell lung cancer: a fading effect? J Clin Oncol 2008;26(31):5014-7.

7. Travis WD, Colby TV, Corriu B, et al. Histological typing of lung and pleural tumours. Berlin: Springer; 1999.

8. Travis WD, Brambilla E, Riely GJ. New pathologic classification of lung cancer: relevance for clinical practice and clinical trials. J Clin Oncol 2013;31(8):9921001.

9. Goldstraw P. New staging system: how does it affect our practice? J Clin Oncol 2013;31(8):984-91.

10. Postmus PE, Kerr KM, Oudkerk M, et al. Early and locally advanced non-small-cell lung cancer (NSCLC): ESMO Clinical Practice Guidelines for diagnosis, treatment and follow-up. Ann Oncol 2017;28 (suppl_4):iv1-iv21.

11. Cox DR. Regression Models and life tables. J Royal Stat Soc 1972;4:187-220.

12. Hosmer DW, Lemeshow S, May S. Assessment of Model Adequacy. In Applied Survival analysis.Regression Modeling of Tine-to-Event Data. Edited by Badling JD, Cressie NAC, Fitzmaurice GM. Hoboken, Bew Jersey: John Wiley \& Sons, Inc; 2008:169-206.

\section{CONCLUSION}

The clinical profile, and the survival of patients with lung cancer have evolved with an increase percentage of women, and adenocarcinoma subtypes, and an improvement in the survival. Theses epidemiological changes, the introduction of PET, and adjuvant treatments helps the physician for a better characterization of the patients' profile. The patients diagnosed with a late stages have a poorer prognosis than early stages.
13. Lee ET, Go OT. Survival analysis in public health research. Annu Rev Public Health 1997;18:105-34.

14. Torre LA, Siegel RL, Ward EM, et al. International variation in lung cancer mortality rates and trends among women. Cancer Epidemiol Biomarkers Prev 2014;23(6):1025-36.

15. Thun MJ, Lally CA, Flannery JT, et al. Cigarette smoking and changes in the histopathology of lung cancer. J Natl Cancer Inst 1997;89(21):1580-6.

16. Ridge CA, McErlean AM, Ginsberg MS. Epidemiology of lung cancer. Semin Intervent Radiol 2013;30(2):93-8.

17. Powell CA, Halmos B, Nana-Sinkam SP. Update in lung cancer and mesothelioma 2012. Am J Respir Crit Care Med 2013;188(2):157-66.

18. Henley SJ, Richards TB, Underwood JM, et al. Lung cancer incidence trends among men and women-United States, 2005-2009. MMWR Morb Mortal Wkly Rep 2014;63(1):1-5.

19. Gounant V, Khalil A, Crequit P, et al. 2014 update on non-small cell lung cancer (excluding diagnosis). Diagn Interv Imaging 2014

20. Alberg AJ, Brock MV, Ford JG, et al. Epidemiology of lung cancer: Diagnosis and management of lung cancer, 3rd ed: American College of Chest Physicians evidence-based clinical practice guidelines. Chest 2013;143(5 Suppl):e1S-29S.

21. Clement-Duchene C, Vignaud JM, Stoufflet A, et al. Characteristics of never smoker lung cancer including environmental and occupational risk factors. Lung Cancer 2010;67(2):144-50.

22. Paris C, Clement-Duchene C, Vignaud JM, et al. Relationships between lung adenocarcinoma and gender, age, smoking and occupational risk factors: A casecase study. Lung Cancer 2010;68(2):146-53.

23. Sculier JP, Meert AP, Berghmans T. Updates in oncology. Eur Respir Rev 2014;23(131):69-78.

24. Wakelee HA, Chang ET, Gomez SL, et al. Lung cancer incidence in never smokers. J Clin Oncol 2007;25 (5):472-8. 
25. Tyczynski JE, Bray F, Parkin DM. Lung cancer in Europe in 2000: epidemiology, prevention, and early detection. Lancet Oncol 2003;4(1):45-55.

26. Wakelee HA, Wang W, Schiller JH, et al. Survival differences by sex for patients with advanced non-small cell lung cancer on Eastern Cooperative Oncology Group trial 1594. J Thorac Oncol 2006;1(5):441-6.

27. Visbal AL, Williams BA, Nichols FC, 3rd, et al. Gender differences in non-small-cell lung cancer survival: an analysis of 4,618 patients diagnosed between 1997 and 2002. Ann Thorac Surg 2004;78(1):209-15.

28. Ouellette D, Desbiens G, Emond C, et al. Lung cancer in women compared with men: stage, treatment, and survival. Ann Thorac Surg 1998;66(4):1140-3; discussion 43-4.

29. Hanagiri T, Sugio K, Uramoto H, et al. Gender difference as a prognostic factor in patients undergoing resection of non-small cell lung cancer. Surg Today 2007;37(7):546-51.

30. Fu JB, Kau TY, Severson RK, et al. Lung cancer in women: analysis of the national Surveillance, Epidemiology, and End Results database. Chest 2005;127(3):76877.

31. Ferguson MK, Wang J, Hoffman PC, et al. Sexassociated differences in survival of patients undergoing resection for lung cancer. Ann Thorac Surg 2000;69(1):245-9; discussion 49-50.

32. de Perrot M, Licker M, Bouchardy C, et al. Sex differences in presentation, management, and prognosis of patients with non-small cell lung carcinoma. J Thorac Cardiovasc Surg 2000;119(1):21-6.

33. Batevik R, Grong K, Segadal L, et al. The female gender has a positive effect on survival independent of background life expectancy following surgical resection of primary non-small cell lung cancer: a study of absolute and relative survival over 15 years. Lung Cancer 2005;47(2):173-81.

34. Alexiou C, Onyeaka CV, Beggs D, et al. Do women live longer following lung resection for carcinoma? Eur J Cardiothorac Surg 2002;21(2):319-25.

35. Nordquist LT, Simon GR, Cantor A, et al. Improved survival in never-smokers vs current smokers with primary adenocarcinoma of the lung. Chest 2004;126 (2):347-51. d
36. Kogure Y, Ando M, Saka H, et al. Histology and Smoking Status Predict Survival of Patients with Advanced Non-Small-Cell Lung Cancer: Results of West Japan Oncology Group (WJOG) Study 3906L. J Thorac Oncol 2013;8(6):753-58.

37. Itaya $\mathrm{T}$, Yamaoto $\mathrm{N}$, Ando M, et al. Influence of histological type, smoking history and chemotherapy on survival after first-line therapy in patients with advanced non-small cell lung cancer. Cancer Sci 2007;98 (2):226-30.

38. Bryant A, Cerfolio RJ. Differences in epidemiology, histology, and survival between cigarette smokers and never-smokers who develop non-small cell lung cancer. Chest 2007;132(1):185-92.

39. van Tinteren H, Hoekstra OS, Smit EF, et al. Effectiveness of positron emission tomography in the preoperative assessment of patients with suspected non-small-cell lung cancer: the PLUS multicentre randomised trial. Lancet 2002;359(9315):1388-93.

40. Dinan MA, Curtis LH, Carpenter WR, et al. Stage migration, selection bias, and survival associated with the adoption of positron emission tomography among medicare beneficiaries with non-small-cell lung cancer, 1998-2003. J Clin Oncol 2012;30(22):2725-30.

41. Douillard JY, Rosell R, De Lena M, et al. Adjuvant vinorelbine plus cisplatin versus observation in patients with completely resected stage IB-IIIA non-small-cell lung cancer (Adjuvant Navelbine International Trialist Association [ANITA]): a randomised controlled trial. Lancet Oncol 2006;7(9):719-27.

42. Govindan R, Bogart J, Vokes EE. Locally advanced non -small cell lung cancer: the past, present, and future. J Thorac Oncol 2008;3(8):917-28.

43. Strauss GM, Herndon JE, 2nd, Maddaus MA, et al. Adjuvant paclitaxel plus carboplatin compared with observation in stage IB non-small-cell lung cancer: CALGB 9633 with the Cancer and Leukemia Group B, Radiation Therapy Oncology Group, and North Central Cancer Treatment Group Study Groups. J Clin Oncol 2008;26(31):5043-51.

44. Wakelee HA, Schiller JH, Gandara DR. Current status of adjuvant chemotherapy for stage IB non-small-cell lung cancer: implications for the New Intergroup Trial. Clin Lung Cancer 2006;8(1):18-21. 